\title{
THE LEVEL OF KNOWLEDGE INTENSITY OF THE COUNTRY'S ECONOMIC SYSTEM
}

\author{
Grigory Bashnyanin', Valentina Kutsyk², Irena Svidruk ${ }^{3}$
}

\begin{abstract}
The relevance of studying the issues of the knowledge intensity of economic systems has led to the conduct of these studies and determines their scientific and practical significance. The purpose of the study is a multidimensional analysis of the knowledge intensity of the domestic economic system, in particular, its creative potential, the activity of technological modernization of industry, and the creative initiative of economic actors. In the process of research, the EBRD methodology is used to evaluate the development of the knowledge economy, taking into account the specifics of the national organization of official statistical observations. In 2017, more than 1.8 thousand domestic enterprises (in the industrial sector - 1159 enterprises) created and used the latest technologies, innovation proposals, and other objects of intellectual property rights. The highest rates of creative activity were observed steadily among enterprises of information and communication sphere, financial and insurance directions, and also in the field of engineering. The leaders in the production and implementation of technological research and development $(R \& D)$ were processing industry, energy, engineering, professional scientific and advertising activities, non-technological - financial, insurance, information, telecommunication, processing enterprises. By types of economic activity, pharmaceutical companies, manufacturers of precise and extremely-precise equipment, chemical industry enterprises steadily occupied the leading positions in the field of creative activity. The analysis of regional dynamics shows the general tendency of reduction in the number of industrial enterprises that created, used or distributed creative developments. In general, during the period of research, the creative activity of enterprises decreased by almost a third, and downward processes are characteristic for almost all regions of Ukraine. In 2017, 2387 product innovations were introduced by the objects of industry, including innovative devices, equipment, machines, most of which were new for the relevant market. Today, there is a sufficient scientific and practical foundation for the development of creative clusters in hightech sectors. However, these processes are hampered over the lack of budget allocations. There is a tendency of increasing R\&D financing by leading industrial enterprises, establishing the practice of their acquisition of hightech equipment and related technologies. In 2016-2017, there was a restructuring of investment flows, which manifested in reducing the costs of R\&D intellectual components and reorientation of financial flows towards the acquisition of modern production equipment. In order to implement their own creative and innovative programs, in 2017, enterprises acquired 832 new technologies, most of which were completed with the corresponding equipment. By industrial enterprises, 59 creative technological developments were created and transferred to other entities. Total investments in updating domestic industrial enterprises amounted to more than 9.1 billion hryvnias in 2017. By types of economic activity, the leaders were the machinery and equipment industry and the food industry. Conclusions. Therefore, the significant creative potential of the domestic industry, further enhanced by active cooperation with scientific institutions, can become the basis for structural transformation and a source of scientific and technological "breakthrough" of our state.
\end{abstract}

Key words: high-tech sector of economy, creative activity, creative cluster, creative initiative, technological modernization, technological research and development.

JEL Classification: E22, F63, G14, P27

\footnotetext{
Corresponding author:

${ }^{1}$ Lviv University of Trade and Economics, Ukraine.

E-mail: lute@lute.lviv.ua

${ }^{2}$ Lviv University of Trade and Economics, Ukraine.

E-mail: lute@lute.lviv.ua

${ }^{3}$ Lviv University of Trade and Economics, Ukraine.

E-mail: irena_svidruk@ukr.net
} 


\section{Introduction}

Irreversible integration of Ukraine in the world economic system extremely actualizes the issue of improvement of knowledge intensity status of the domestic economy because today there is a rather high risk of occupying the place of an exporter of cheap human resources or becoming an agro-raw material supplier for developed countries. At the same time, the current trends in the development of the national economy confirm its steady direction towards the creation of high-tech competitive products with high added value. The degree of conformity of applied technologies and equipment to the requirements of the high-tech environment determines the cost, resource, and energy intensity of production processes. Consequently, the value of knowledge intensity of competitive production, which is based on scientific research, relations between scientific knowledge and production processes, continuous self-training of creative personnel, increases. The inadequacy of studying the issues of knowledge intensity of economic systems has led to these studies and determines their scientific and practical significance.

The purpose of this study is a multidimensional analysis of the knowledge intensity of the domestic economic system, which is based on the creative potential and technological modernization of industry.

In the process of research, the EBRD methodology for evaluating the development of the knowledge economy, taking into account the specifics of the national organization of official statistical observations, is used.

\section{Development of creative potential in countries of Central and Eastern Europe}

Modern challenges of the rapid development of a globalized society elevate the problems of intensified knowledge management development to higher levels of priority of the world economic community. These trends are conditioned, first of all, by the etiological factors of the formation and development of the knowledge economy, in particular, the rapid growth of knowledge intensity, intellectualization and high technology of production, which entails the need for a significant increase in labour productivity and actualizes the emergence of the newest post-industrial market segments.

The economic processes of the countries of Central and Eastern Europe in recent years are characterized by the intensification of knowledge management. One of the recognized leaders in building an information society among them is Poland, which recently is actively increasing the potential of the IT industry and invested more than 3.5 billion USD in the high-tech sector and attracted more than 500 thousand specialists. An interesting feature of Poland's creative economy is that its subjects are mostly small enterprises. Successful informatisation of the society is promoted by state support for the development of high-tech production. In the meantime, despite the significant strengthening of the creative potential of the countries of Central and Eastern Europe in recent years, the main development indicators still do not reach the corresponding indicators of the leading countries (Table 1).

In particular, the level of expenditures on $R \& D$ remains much lower, which negatively affects the dynamics of creative economic development. Processes of strengthening the personnel potential of science require intensification that would increase the share of employed in high-tech industries and qualitatively influence other indicators of creative activity, in particular, the processes of scientific and production cooperation and development of high technology industries.

In 2013-2017, there was a tendency for expanded involvement of private business representatives in knowledge-intensive and high-tech industrial production, in particular, in the fields of pharmaceuticals, electronics, and communications, which greatly

Table 1

The level of creative potential of the countries of Central and Eastern Europe in 2017

\begin{tabular}{|l|c|c|c|c|c|}
\hline Country & $\begin{array}{c}\text { The share of science } \\
\text { expenditure in GDP, } \\
\%\end{array}$ & $\begin{array}{c}\text { Number of researchers } \\
\text { (per 1 million } \\
\text { population) }\end{array}$ & $\begin{array}{c}\text { The share of high-tech } \\
\text { products in commodity } \\
\text { exports, \%, }\end{array}$ & $\begin{array}{c}\text { Cooperation } \\
\text { of science and } \\
\text { business, \% }\end{array}$ & $\begin{array}{c}\text { The intensity } \\
\text { of competition } \\
\text { at the local level, \% }\end{array}$ \\
\hline Bulgaria & 0,53 & 1586,7 & 7,9 & 0,16 & 0,29 \\
\hline Estonia & 1,44 & 3210,3 & 9,1 & 0,77 & 0,80 \\
\hline Latvia & 0,46 & 1601,2 & 7,6 & 0,60 & 0,42 \\
\hline Lithuania & 0,84 & 2541,1 & 10,6 & 0,78 & 0,54 \\
\hline Poland & 0,68 & 1597,6 & 6,7 & 0,54 & 0,73 \\
\hline Romania & 0,48 & 894,8 & 10,9 & 0,17 & 0,30 \\
\hline Serbia & 0,88 & 1060,1 & 0,59 & 0,02 & \\
\hline Slovakia & 0,48 & 2437,7 & 7,1 & 0,46 & 0,74 \\
\hline Slovenia & 0,85 & 3678,8 & 5,5 & 0,65 & 0,64 \\
\hline Hungary & 1,15 & 2006 & 24,2 & 0,77 & 0,73 \\
\hline Croatia & 0,83 & 1571,3 & 9,2 & 0,45 & 0,17 \\
\hline Czech Republic & 1,52 & 2754,8 & 15,3 & 0,79 & 0,89 \\
\hline
\end{tabular}


increased the competitiveness of the corresponding products. However, an indicator of competitive intensity at the local level (one of the indicators of the Global Innovation Index) in Central and Eastern European countries still does not reach the level of economically advanced countries.

The low creative activity of enterprises is conditioned, first of all, by the lack of financial resources for the qualitative disclosure of creative potential. The lack of foreign investment in high-tech sectors of the economy requires an increase in the enterprises' own resources and the search for opportunities for state support. However, in most countries of Central and Eastern Europe, at the initial stage of economic transformation, there was a separation of state institutions from investing in the scientific and technical sphere. At the next stage, this became one of the reasons for the technological lag behind the leading countries and led to the need to develop appropriate "catching-up development" strategies aimed at the rapid economic growth and technological breakthroughs. In order to implement such strategies, tools for attracting foreign capital, developing export-oriented models of the economy, and concentrating domestic financial resources on hightech production lines are actively used.

The adaptation of the national economies of Central and Eastern European countries to the realities of the post-industrial structure requires a reorientation to the latest development model based on the dominant development of the existing intellectual, creative, and scientific and technical potential. Priority is given to the production of original knowledge and technologies, and the corresponding institutional means of stimulating activities in the field of high technologies such as electronics, nanostructured chemicals, energy, and biotechnology are created. Correspondingly, diversification of managerial tools for the creation and diffusion of new knowledge and facilitation of access to databases and intelligent systems are envisaged by the state strategic development programs.

\section{Ukrainian industry's creative potential}

In 2013-2017, the share of enterprises that carried out scientific and technological innovations in their activities amounted to $18.4 \%$, of which $11.8 \%$ of enterprises declared technological updating, including $5.7 \%$ of enterprises created product innovations, $10.3 \%$ - introduced process innovations. Out of $13.4 \%$ of enterprises engaged in non-technological creative developments, $8.7 \%$ relate to organizational innovations and $10.2 \%$ to market developments (State Statistics Service of Ukraine, 2018).

In the service sector, creative and innovative entrepreneurship in Ukraine is most often represented by Internet entrepreneurs, web-specialists, and creative studios with creative authoring services. These areas are most highly characterized by high flexibility and adaptability, which allows levelling high risks of implementing creative projects and, if necessary, making managerial decisions for the rapid conversion of research programs and diversification of their areas of use.

In addition to enterprises of IT services, the largest creative and innovative activity in 2013-2017 was shown by large enterprises with a number of attracted personnel of 250 or more persons (an average, 39.6\% of all enterprises of this type) while the shares of innovationactive enterprises in the medium and small business were $24.7 \%$ and $14.8 \%$, respectively. It is clear that the refusal of the majority of small and medium-sized enterprises from high-tech creative developments indicates, first of all, their efforts to avoid additional risks that can substantially burden already imperfect financial and economic opportunities. At the same time, the low creative activity of powerful industrial enterprises directly indicates the steady orientation of the existing development model of the national economic system to low-tech production and in general significantly reduces competitive positions of the industrial sector (Sobkevych, Sukhorukov, Shevchenko, Krupeljnycjka, 2013). Alongside with that, the significant creative potential of the domestic industry, further enhanced by active cooperation with scientific institutions, can become the basis for structural transformation and a source of scientific and technological "breakthrough" of our state.

\section{Technological modernization of Ukrainian industrial complex}

The national industrial sector requires active use of creative management schemes capable of directing the vector of innovation development towards the development of scientific and technological potential. This will contribute to improving the competitiveness of products manufactured by using the latest technology and innovative production equipment. The additional effects of creative and technological modernization of the domestic industrial complex, capable of providing its sectoral restructuring, are the access to new markets (and hence - increase of sales volumes and improvement of financial results) and updating of the scientific and technological base of production (with the corresponding optimization of production processes).

In 2017, more than 1.8 thousand domestic enterprises created and used the latest technologies, innovation proposals, and other objects of intellectual property rights; in particular, in the industrial sector of the domestic economy, 1159 enterprises used R\&D results (Table 2). During 2013-2017, the highest rates of creative activity were observed steadily among enterprises of information and communication sphere (22.1\% of all enterprises of this sector), financial and insurance directions $(21.7 \%)$, and also in the field of engineering $(20.1 \%)$. 
Table 2

Distribution of creative active enterprises by industry in 2017 (units)

\begin{tabular}{|c|c|c|c|c|c|}
\hline & & & Number of & terprises that & \\
\hline & Total & $\begin{array}{l}\text { created advanced } \\
\text { technology }\end{array}$ & $\begin{array}{l}\text { used advanced } \\
\text { technology }\end{array}$ & $\begin{array}{l}\text { used intellectual } \\
\text { property objects }\end{array}$ & $\begin{array}{l}\text { used innovative } \\
\text { suggestions }\end{array}$ \\
\hline Total for Ukraine & 1835 & 135 & 1669 & 368 & 203 \\
\hline Industry & 1159 & 44 & 1127 & 222 & 75 \\
\hline $\begin{array}{l}\text { Wholesale and retail trade; repair of } \\
\text { motor vehicles }\end{array}$ & 54 & 2 & 38 & 2 & 27 \\
\hline $\begin{array}{l}\text { Transport, warehousing, postal and } \\
\text { courier activities }\end{array}$ & 218 & 1 & 203 & 24 & 14 \\
\hline Information and telecommunications & 112 & 27 & 71 & 34 & 63 \\
\hline $\begin{array}{l}\text { Professional, scientific and technical } \\
\text { activities }\end{array}$ & 217 & 36 & 172 & 59 & 14 \\
\hline incl. research and development & 91 & 27 & 78 & 43 & 10 \\
\hline $\begin{array}{l}\text { Public administration and defence, } \\
\text { compulsory social insurance }\end{array}$ & 7 & 5 & 1 & - & 2 \\
\hline Education & 46 & 18 & 39 & 23 & 4 \\
\hline Health care and social assistance & 21 & 1 & 18 & 4 & 4 \\
\hline Provision of other types of services & 1 & 1 & - & - & - \\
\hline
\end{tabular}

Regarding the introduction of technological R\&D by the domestic industrial enterprises, the leaders are such branches as processing industry $(15.6 \%$ of all enterprises of the industry), energy (12.6\%), engineering, professional scientific and advertising activities (13.2\% each). The leaders in the production and implementation of non-technological innovation in the studied period were financial and insurance enterprises (18.0\% of all enterprises of the industry), information and telecommunication (17.3\%), and also processing enterprises (15.3\%).

By types of economic activity in 2013-2017, pharmaceutical companies (53.8\% of all enterprises of the industry), vehicle manufacturers (37.1\%), manufacturers of electronic and optical products $(34.0 \%)$, precise and extremely-precise equipment (25.2\%), and chemical industry enterprises (25.0\%) steadily occupied the leading positions in the field of creative activity.

\section{Technology transfer}

Sustained trends in the growth of the role of creative potential for innovation in industrial development require adequate managerial regulation in the field of technology transfer from the academic science sector, the creation of effective mechanisms for the R\&D commercialization and stakeholder cooperation. For the consolidation of information resources of state and public institutions, innovative enterprises, and scientific organizations in a single network, a pilot project "Ukrainian Technology Transfer Network UTTN" was created. Technology transfer for the purpose of integration into European transfer networks is defined as the institutional purpose of the formation, which involves increasing the efficiency of using the domestic intellectual potential, commercialization of $\mathrm{R} \& \mathrm{D}$ of academic universities and research institutions, reorientation of the industry to the production of high-tech products (Novikov, 2015). Creation of EEN-Ukraine Consortium has defined the businesstechnology cooperation of innovative enterprises and scientific organizations of Ukraine and the EU. One should also note transfer activity of the Ukrainian Institute of Scientific and Technical Expertise and Information, which regulates Ukraine's partner relations with the international community and promptly provides business structures and scientific organizations with scientific and technical information through an automated system for the formation of integrated interstate information resources.

The general megatrends of a globalized society, which include demographic changes, urbanization on the basis of the fullest possible automation, comprise elements of uncertainty and cause insecurity of the future development of the economic structure, which can be overcome only through persistent creative searches and corresponding infrastructure transformations. The creative planning of strategic directions for future business development allows creating potential technological update scenarios and timely predicting possible obstacles to radical change. In this sense, institutional support for the renewed imperatives and private-public partnership program is extremely important in order to financially support creative initiatives that stimulate the innovative transformation of the industrial sector of the national economic system, contributing to economic growth, environmental responsibility principles, and social progress.

The growth of creative activity of enterprises requires the use of new organizational levers to stimulate productivity growth, develop a creative product 
with high added value, and develop high-tech and knowledge-intensive industries (Paschenko, 2017). Unfortunately, the general trends in the development of the national industrial sector still cannot be considered sufficiently creative. According to the findings of the World Economic Forum-2018 in Davos, the levels of technological effectiveness and energy efficiency of the domestic industry significantly lag behind similar indicators of the European Community countries, while the share of hi-tech product in exports remains negligible (World Economic Forum ${ }^{\circledast}, 2018$ ).

More than half of the cases of the technological innovation of industrial enterprises took place through the purchase of new equipment and software. The analysis of the dynamics of the regional distribution of industrial enterprises, which used the $R \& D$ results in the economic activity in 2013-2017, is presented in Table 3 and shows a general tendency of reduction in the number of industrial enterprises that created, used or distributed creative developments. In general, during the study period, the creative activity of enterprises decreased by almost a third, and downward processes are characteristic for almost all regions of Ukraine.

The worst indicators of dynamics are observed in the Luhansk region (reduction by $85.2 \%$ ), which can be explained by the complex socio-economic situation in the region over the hybrid aggression of the Russian Federation. Among the other outsiders, the worst dynamics are observed in Rivne (reduction by $79.5 \%$ ), Chernivtsi (by 66.7\%), and Donetsk (by 63.5\%) regions. Three regions in 2017 slightly exceeded similar indicators in 2013, namely, Poltava (by 3.0\%), Kharkiv (by 3.3\%), Dnipropetrovsk (by $6.0 \%$ ) regions, and sufficient growth rates of the use of $\mathrm{R} \& \mathrm{D}$ results in economic activity are observed only in Volyn (by 21.7\%) and Vinnytsia (by 21.8\%) regions.

At the same time, it should be noted that the downward trends of 2013-2017 are mainly determined by the general downturn in 2014-2015, after which positive trends began to recover in the national economy. Therefore, in comparison with the previous year, the majority of regions show an increase in the number of creative enterprises (somewhat significant). Leaders in this direction are Vinnytsia (increase by $45.7 \%$ ) and Volyn (by $40.0 \%$ ) regions. In 2017, activities above the average in Ukraine were demonstrated by enterprises in Kharkiv (28.1\% of enterprises of the region), Ternopil (27.5\%), Mykolaiv (26.9\%) regions and the city of Kyiv (20.7\%). At the same time, the lowest indicators are observed in Khmelnytskyi (5.7\% of enterprises of the region), Rivne (5.9\%), and Zakarpattia (9.0\%) regions.

Table 3

The research activity of industrial enterprises of Ukraine in 2013-2017 by regions (according to data of the State Statistics Service of Ukraine, 2018)

\begin{tabular}{|c|c|c|c|c|c|c|c|}
\hline Region & 2013 & 2014 & 2015 & 2016 & 2017 & $2017 / 2016, \%$ & $2017 / 2013, \%$ \\
\hline Total for Ukraine & 1715 & 1609 & 824 & 991 & 1159 & 117,0 & 67,6 \\
\hline Vinnytsia region & 55 & 46 & 25 & 46 & 67 & 145,7 & 121,8 \\
\hline Volyn region & 23 & 30 & 12 & 20 & 28 & 140,0 & 121,7 \\
\hline Dnipropetrovsk region & 84 & 109 & 63 & 76 & 89 & 117,1 & 106,0 \\
\hline Donetsk region & 85 & 45 & 28 & 30 & 31 & 105,1 & 36,5 \\
\hline Zhytomyr region & 57 & 48 & 28 & 30 & 31 & 105,1 & 54,4 \\
\hline Transcarpathian region & 15 & 16 & 14 & 13 & 12 & 92,3 & 80,0 \\
\hline Zaporizhzhia region & 115 & 108 & 49 & 56 & 62 & 111,7 & 53,9 \\
\hline Ivano-Frankivsk region & 87 & 99 & 27 & 32 & 36 & 114,3 & 41,4 \\
\hline Kyiv region & 68 & 66 & 44 & 41 & 37 & 91,4 & 54,4 \\
\hline Kirovohrad region & 46 & 49 & 25 & 31 & 37 & 119,4 & 80,4 \\
\hline Luhansk region & 61 & 16 & 9 & 9 & 9 & 100,0 & 14,8 \\
\hline Lviv region & 116 & 129 & 64 & 67 & 69 & 103,8 & 59,5 \\
\hline Mykolaiv region & 81 & 67 & 29 & 31 & 32 & 104,9 & 39,5 \\
\hline Odesa region & 69 & 67 & 36 & 36 & 36 & 100,0 & 52,2 \\
\hline Poltava region & 33 & 33 & 30 & 32 & 34 & 106,3 & 103,0 \\
\hline Rivne region & 39 & 45 & 13 & 11 & 8 & 76,2 & 20,5 \\
\hline Sumy region & 32 & 46 & 23 & 24 & 24 & 102,1 & 75,0 \\
\hline Ternopil region & 36 & 36 & 16 & 23 & 29 & 128,9 & 80,6 \\
\hline Kharkiv region & 182 & 191 & 117 & 153 & 188 & 123,3 & 103,3 \\
\hline Kherson region & 48 & 54 & 19 & 25 & 31 & 124,0 & 64,6 \\
\hline Khmelnytskyi region & 58 & 38 & 18 & 24 & 29 & 123,4 & 50,0 \\
\hline Cherkasy region & 47 & 37 & 25 & 29 & 32 & 112,3 & 68,1 \\
\hline Chernivtsi region & 30 & 34 & 9 & 10 & 10 & 105,3 & 33,3 \\
\hline Chernihiv region & 45 & 32 & 15 & 26 & 36 & 141,2 & 80,0 \\
\hline Kyiv & 142 & 168 & 86 & 124 & 162 & 130,6 & 114,1 \\
\hline
\end{tabular}


An analysis of the structural content of the activity of introducing the R\&D results into practical activity characterizes its certain unevenness. In particular, the latest creative technologies were most actively implemented by enterprises in Rivne (19.1\% out of all enterprises of the region), Kharkiv (18.7\%), and Kirovohrad (14.7\%) regions; the leaders of nontechnological upgrade were innovation enterprises in the city of Kyiv ( $17.8 \%$ out of all enterprises), as well as Ivano-Frankivsk and Kyiv regions (15.1\% each).

\section{A creative initiative of economic entities}

According to the sustainable development concept, the country's economic growth in the long run depends, first of all, on intensive factors of expanded reproduction, which necessarily requires the implementation of achievements of the domestic and world academic and applied science and technological re-equipment of production processes in the economic practice. A significant role in these processes belongs to the regulatory socio-economic policy, which mediates institutional functions of regulating the innovation development of industry and develops financial mechanisms for industrial reorganization. However, the main lever of the transformational breakthrough of the economic system in a knowledge economy is the management of the development of the creative initiative of economic entities. The main result of the creative activity of industrial enterprises is the creation, promotion, and transfer of a new product. In total in 2017, 672 industry facilities introduced 2387 product innovations (in 2016 their number was 3136), 751 of which - innovative devices, equipment, machinery. Herewith, $80 \%$ of the products introduced were new for the relevant market (Table 4).

1831 new or improved technological processes were implemented (in 2016 - 1217). Leaders of introduction in 2016-2017 are enterprises in Kharkiv (12.6\% of the total number of technological innovations in 2017 and $17.4 \%$ in 2016 ), Sumy (12.3\% and $15.2 \%$ respectively), and Zaporizhzhia (7.8\% and 9.4\% respectively) regions. Industry leaders in 2017 became machine-building enterprises (18.8\%), gas-extraction companies (17.7\%), and manufactures of finished metal products (13.4\%). In 2017, 611 new low-waste and/or resource-saving technologies were introduced in industry, while in 2016 - 458. Regional leaders were enterprises in Kharkiv

Table 4

A number of enterprises that implemented the R\&D results in 2017, by regionality and types of innovations (according to data of the State Statistics Service of Ukraine, 2018)

\begin{tabular}{|c|c|c|c|c|c|c|}
\hline \multirow[b]{2}{*}{ Region } & \multirow[b]{2}{*}{ Total enterprises } & \multicolumn{3}{|c|}{ Innovative products } & \multicolumn{2}{|c|}{ Innovative processes } \\
\hline & & of all & $\begin{array}{c}\text { new to the } \\
\text { market }\end{array}$ & $\begin{array}{l}\text { new for the } \\
\text { enterprise }\end{array}$ & of all & $\begin{array}{c}\text { low-waste, } \\
\text { resource-saving }\end{array}$ \\
\hline Total for Ukraine & 672 & 358 & 90 & 302 & 456 & 198 \\
\hline Vinnytsia region & 15 & 11 & 5 & 10 & 8 & 5 \\
\hline Volyn region & 16 & 4 & 1 & 3 & 8 & 5 \\
\hline Dnipropetrovsk region & 46 & 18 & 5 & 16 & 40 & 11 \\
\hline Donetsk region & 22 & 12 & 3 & 11 & 19 & 11 \\
\hline Zhytomyr region & 23 & 9 & 1 & 8 & 10 & 3 \\
\hline Transcarpathian region & 12 & 4 & - & 4 & 7 & 6 \\
\hline Zaporizhzhia region & 37 & 26 & 6 & 22 & 21 & 7 \\
\hline Ivano-Frankivsk region & 23 & 15 & - & 15 & 16 & 10 \\
\hline Kyiv region & 37 & 16 & 4 & 14 & 28 & 4 \\
\hline Kirovohrad region & 15 & 12 & 2 & 10 & 9 & 6 \\
\hline Luhansk region & 5 & 3 & - & 3 & 4 & 3 \\
\hline Lviv region & 47 & 24 & 8 & 20 & 40 & 12 \\
\hline Mykolaiv region & 16 & 8 & 3 & 5 & 8 & 2 \\
\hline Odesa region & 35 & 15 & 3 & 13 & 28 & 22 \\
\hline Poltava region & 23 & 15 & 1 & 14 & 13 & 2 \\
\hline Rivne region & 7 & 3 & - & 3 & 6 & 2 \\
\hline Sumy region & 18 & 17 & 8 & 12 & 8 & 5 \\
\hline Ternopil region & 25 & 7 & 2 & 5 & 23 & 4 \\
\hline Kharkiv region & 105 & 55 & 17 & 44 & 68 & 38 \\
\hline Kherson region & 15 & 11 & 3 & 11 & 11 & 2 \\
\hline Khmelnytskyi region & 8 & 3 & - & 3 & 6 & 2 \\
\hline Cherkasy region & 31 & 15 & 3 & 13 & 19 & 7 \\
\hline Chernivtsi region & 8 & 7 & - & 7 & 6 & 4 \\
\hline Chernihiv region & 10 & 7 & 2 & 5 & 9 & 6 \\
\hline Kyiv & 73 & 41 & 13 & 31 & 41 & 19 \\
\hline
\end{tabular}


(16.6\% of all innovative products), Zaporizhzhia (13.4\%), and Lviv (10.3\%) regions.

\section{The cluster-innovative scenario of Ukraine's economic development}

The latest trend in the development of creative entrepreneurship is its adaptation to the clusterinnovative scenario of the development of a knowledge economy, in particular, the creation on the basis of large industrial enterprises of the kind of accompanying companies whose main task is the activation of the $\mathrm{R} \& \mathrm{D}$ and the introduction of creative developments. The concept of a creative cluster is considered to be an integral system covering a complete chain of creative development: from the development of a fundamental scientific idea to the production and distribution of a finished innovative product (Shovkaljuk, 2016). It should be noted that the majority of domestic clusters are oriented towards traditional industries, while in the EU countries priority is given to innovative clusters that combine high-tech productions into high-tech industries, playing the role of points of creative growth in the economy (Alslev Christensen, zu Kocker, LammerGamp, Thomsen, Olesen, 2011). Today in Ukraine, there is created a sufficient scientific and practical basis for the development of creative clusters in high-tech sectors. In particular, on the basis of existing industrial parks and technopolises, clusters of biotechnology, electronics, automobile industry etc. can actively develop. However, these processes are hampered by the lack of budget allocations, while in Great Britain, France, Germany, the share of budget investments in technology parks is $65-80 \%$, in Belgium - almost $100 \%$ (Mazur, Shovkaljuk, 2015). In addition, an important push for technological modernization of production, investing in high-tech modern equipment in modern conditions is the potential opportunity to engage the enterprise in infrastructure development of the region, which became possible after the introduction of the ProZorro Unified Electronic Procurement System.

\section{Investment maintenance of technological renovation of the economy}

Traditionally, innovation costs in Ukraine are mostly financed by enterprises on their own. In 2017, only 8 enterprises were financed from the state budget, and 17 other industrial enterprises were financed from local budgets. Only 5 industrial enterprises received funds of domestic investors and 3 - foreign ones, 21 enterprises turned to lending services. Despite the lack of significant progress in the innovation activity of the domestic industry, the cost of technological upgrades is steadily increasing. In addition, there is a tendency of increasing R\&D financing by leading industrial enterprises, as well as establishing the practice of their acquisition of high- tech equipment and related technologies. Note that in 2016-2017, there was a restructuring of investment flows in domestic creative entrepreneurship, which manifested in reducing the costs of R\&D intellectual components and reorientation of financial flows towards the acquisition of modern production equipment. The dynamics of the investment component of the creative activity of the domestic industrial sector in the regional section is shown in Table 5. As we see, the largest activity in the period of 2013-2017 was stably demonstrated by industrial enterprises in Zaporizhzhia, Dnipropetrovsk, Kharkiv regions. However, the dynamic analysis shows negative trends regarding the possibilities of investing in R\&D, technological or product updates, which confirms our observations on the impact of general economic instability in the state on the willingness of enterprises to invest extra funds in the system technological upgrade of production. In order to implement their own creative and innovative programs in 2017, 170 enterprises acquired 832 new technologies (of which 129 - import), including 386 technologies (81 - import) were completed with the corresponding equipment. Moreover, 305 new technologies were the result of $R \& D$, more than 100 received as an object of intellectual property rights, 10 - under national and international agreements for the acquisition of technology and know-how. In 2017, Ukraine's industrial enterprises also created and transferred 59 creative technological developments to other economic entities, of which two were exported.

The highest rates of decline in $\mathrm{R} \& \mathrm{D}$ financing by industrial enterprises are recorded in Luhansk (by $94.6 \%$ less than in 2013), Zhytomyr (by $85.8 \%$ ), and Vinnytsia (by $85.6 \%$ ) regions. At the same time, some regions show a certain investment "breakthrough", increasing investment in creative development more than 4 times. Undeniable leaders of growth are Zaporizhzhia (4.7 times more than in 2013), Ternopil (4.5 times), Kirovohrad and Cherkasy (more than 4.4 times each) regions. Compared to 2016, the regional dynamics seems somewhat more balanced, with no significant fluctuations, but the general tendency to reduce investment in R\&D and high-tech equipment is noticeable. The worst indicators of rates of change are observed in Ternopil (by 76.5\% less than in 2016), Dnipropetrovsk (by 74.1\%), and Vinnytsia (by 70.3\%) regions. The leaders of growth are Zaporizhzhia (by $62.6 \%$ more than in 2016), Kirovohrad (by 59.6\%), and Sumy (by $57.3 \%$ ) regions.

Total investments in production, technological, and organisational update of domestic industrial enterprises amounted to more than 9.1 billion UAH in 2017 , where 2.2 billion UAH (24.2\%) was spent on the development of own and acquisition of foreign $\mathrm{R} \& \mathrm{D}$ and technology, 5.9 billion UAH (64.8\%) was directed to the purchase of equipment and software, 1.1 billion UAH (11.3\%) - to other works related 
Table 5

Dynamics of industrial enterprises' expenditures on R\&D in 2013-2017, million UAH (according to data of the State Statistics Service of Ukraine, 2018)

\begin{tabular}{|l|c|c|c|c|c|c|c|}
\hline \multicolumn{1}{|c|}{ Region } & 2013 & 2014 & 2015 & 2016 & 2017 & $2017 / 2016, \%$ & $2017 / 2013, \%$ \\
\hline Total for Ukraine & 9562,6 & 7695,9 & 13813,7 & 11465,6 & 9117,5 & 79,5 & 95,3 \\
\hline Vinnytsia region & 694,9 & 796,5 & 575,3 & 337,9 & 100,4 & 29,7 & 14,4 \\
\hline Volyn region & 196,3 & 192,5 & 65,3 & 113,7 & 162,1 & 142,6 & 82,6 \\
\hline Dnipropetrovsk region & 1057,8 & 825,2 & 7568,9 & 4348,1 & 1127,3 & 25,9 & 106,6 \\
\hline Donetsk region & 930,7 & 516,1 & 827,6 & 776,5 & 725,3 & 93,4 & 77,9 \\
\hline Zhytomyr region & 73,1 & 60,6 & 32,6 & 21,5 & 10,4 & 48,4 & 14,2 \\
\hline Transcarpathian region & 25 & 16,6 & 22,5 & 24,4 & 26,2 & 107,6 & 104,8 \\
\hline Zaporizhzhia region & 298,7 & 339,9 & 321 & 857,2 & 1393,4 & 162,6 & 466,5 \\
\hline Ivano-Frankivsk region & 488,6 & 95,8 & 92,2 & 113,2 & 134,2 & 118,6 & 27,5 \\
\hline Kyiv region & 104,4 & 122,1 & 144,8 & 217,3 & 289,7 & 133,3 & 277,5 \\
\hline Kirovohrad region & 114,8 & 93 & 127,7 & 316,0 & 504,2 & 159,6 & 439,2 \\
\hline Luhansk region & 372,5 & 35,1 & 24,3 & 22,3 & 20,2 & 90,8 & 5,4 \\
\hline Lviv region & 257,1 & 219,7 & 277,8 & 294,0 & 310,1 & 105,5 & 120,6 \\
\hline Mykolaiv region & 716,4 & 606,8 & 291,6 & 308,3 & 324,9 & 105,4 & 45,4 \\
\hline Odesa region & 91 & 323,9 & 49,7 & 99,9 & 150,1 & 150,3 & 164,9 \\
\hline Poltava region & 212,2 & 348,5 & 128,5 & 98,4 & 68,2 & 69,3 & 32,1 \\
\hline Rivne region & 21,1 & 11,4 & 6,9 & 7,1 & 7,3 & 102,8 & 34,6 \\
\hline Sumy region & 281,8 & 587,7 & 162,3 & 380,4 & 598,5 & 157,3 & 212,4 \\
\hline Ternopil region & 24,2 & 57,4 & 14,6 & 62,2 & 109,7 & 176,5 & 453,3 \\
\hline Kharkiv region & 642,3 & 711,1 & 667 & 779,0 & 890,9 & 114,4 & 138,7 \\
\hline Kherson region & 161,4 & 90,5 & 70,1 & 63,1 & 56,1 & 88,9 & 34,8 \\
\hline Khmelnytskyi region & 113,1 & 133,1 & 66,7 & 45,7 & 24,6 & 53,9 & 21,8 \\
\hline Cherkasy region & 28,6 & 30,4 & 53,5 & 89,1 & 124,7 & 140,0 & 436,0 \\
\hline Chernivtsi region & 51,3 & 68,8 & 18,8 & 22,5 & 26,1 & 116,3 & 50,9 \\
\hline Chernihiv region & 134,1 & 106,4 & 35 & 53,4 & 71,7 & 134,4 & 53,5 \\
\hline Kyiv & 1921,4 & 1306,8 & 2169 & 2015,1 & 1861,2 & 92,4 & 96,9 \\
\hline
\end{tabular}

with the generation and transfer of knowledge (in particular, education, projecting, marketing). By types of economic activity, the leaders of investment in the scientific and technical upgrade of industrial enterprises in 2017 were the machinery and equipment industry (1.23 billion UAH or $13.5 \%)$ and the food industry (1.14 billion UAH or $12.6 \%$ ).

\section{Intellectual creative activities of Ukrainian economic entities}

The largest volumes of intellectual creative activity and $R \& D$ in Ukraine traditionally belong to higher education and research establishments. Consequently, the implementation of a business creativitization policy requires enterprises to fully develop multifaceted links between science and industry and to take full advantage of opportunities of both scientific infrastructure and such modern tools as clusters and industrial-production zones. In general, over $34.4 \%$ of creative enterprises cooperated with scientific institutions, universities, research institutes in the period of 2013-2017. At the same time, in 2017 , only $8.4 \%$ of such enterprises cooperated with scientific organizations, and their main partners were suppliers of equipment, materials, and information resources (including software).
In 2017, in the whole for Ukraine, 450 industrial enterprises were engaged in the sale of creative products, and the total sales amounted to 17.7 billion UAH. In 2016, these indicators were, respectively, 570 enterprises and 20.4 billion UAH, including 5.5 billion UAH were export deliveries (in $2016-10.8$ billion UAH). About a third of domestic creative product belongs to software and high technology. The volume of the latest for the corresponding product market was 4.5 billion UAH, $41.5 \%$ of which was exported (in 2016, respectively, 7.3 billion UAH and 58.3\%).

Creative developments of the domestic industry for 2013-2017 show the extraordinary potential of creative cooperation between business and science, which allows confidently asserting the possibility of the technological breakthrough of industrial high-tech and future leadership positions in the system of the sixth technological mode. Unfortunately, this indicator has been decreasing more than 2 times in Ukraine as a whole, while among the regions during this period only Cherkasy (with a slight increase by $2.9 \%$ compared to 2013), Chernihiv (growth of more than 2.3 times), and Zaporizhzhia (more than 2.4 times) regions have shown positive dynamics. The rest of Ukraine's regions in 2017 implemented their own creative product less than in 2013. Compared to 2016, the results are 
somewhat better, however, in general in Ukraine and in most regions in 2017 there is still a decrease in sales by industrial enterprises of their own creative products. Industrial objects in Vinnytsia (by $40.5 \%$ more than in 2016), Chernihiv (by 156.5\%), and Mykolaiv (by $170.8 \%$ ) regions show the best results of growth.

\section{Conclusions}

Thus, the creative potential of the domestic economic system is determined by the ability to create high-tech competitive products based on the integrative cooperation of academic and applied science and economic complexes. In 2017, more than 1.8 thousand enterprises created and used the results of $\& \mathrm{D}$, thelatest technologies, and objects of intellectual property rights. By types of economic activity, the leaders were pharmaceutical companies, manufacturers of vehicles, electronic and optical products, precise and extremely-precise equipment, and chemical industry enterprises. At the same time, there is a tendency of reduction in the number of enterprises that created creative development and implemented them into specific product innovations. Costs for creative projects are mostly financed by own funds of enterprises. Structural reconstruction of investment flows manifested itself in reducing the cost of intellectual components of the $\mathrm{R} \& \mathrm{D}$ in favour of the acquisition of modern production equipment. Consequently, despite significant problems and complexities, the existing creative potential of the domestic economy allows asserting the possibility of implementing a technological breakthrough of industrial high-tech in Ukraine, which will contribute to a faster integration of the national economic system into the world creative community.

\section{References:}

Alslev Christensen T., zu Kocker G., Lammer-Gamp T., Thomsen M., Olesen K. (2011). Cluster and network policy programmes in Europe. Retrieved from: http://files.conferencemanager.dk/medialibrary/f13db635-416d4cbc-a465-78f2ff879 6c6/images/Cluster_policy_programmes in_Northern_Europe Article 2_.pdf

Mazur, O. A., Shovkaljuk, V. S. (2015). Tekhnologhichni parky. Svitovyj ta ukrajinsjkyj dosvid [Technological parks. World and Ukrainian experience]. Kyiv: Brock Business. (in Ukrainian)

Novikov, Je. A. (2015). Suchasni merezhi transferu tekhnologhij i jikh pravovyj status v Ukrajini [Modern technology transfer networks and their legal status in Ukraine]. Right and innovative society, 71(3), 32-37. (in Ukrainian)

Paschenko, O. P. (2017). Kreatyvnyj menedzhment jak faktor uspishnosti suchasnogho biznesu [Creative management as a factor in the success of modern business]. Global and national problems of the economy, 17, 406-410. (in Ukrainian)

Shovkaljuk, V. S. (2016). Klastery ta innovacijnyj rozvytok Ukrajiny [Clusters and innovative development of Ukraine]. Kyiv: State Agency for Science, Innovation and Informatization of Ukraine. Retrieved from: http://www.dknii.gov.ua/images/stories/Stvor_ta_funk_klasteriv.pdf (in Ukrainian)

Sobkevych, O. V., Sukhorukov, A. I., Shevchenko, A. V., Krupeljnycjka, T. P. (2013). Innovatsiinyi rozvytok promyslovosti yak skladova strukturnoi transformatsii ekonomiky Ukrainy [Innovative development of industry as a component of the structural transformation of the Ukrainian economy]. Kyiv: NISS. (in Ukrainian)

State Statistics Service of Ukraine (2018). Nauka, tekhnologhiji ta innovaciji [Science, technology and innovation]. Retrieved from: http://www.ukrstat.gov.ua (in Ukrainian)

World Economic Forum (2018). Future scenarios and implications for the industry. Geneva. Retrieved from: https://www.weforum.org/reports/future-scenarios-and-implications-for-the-industry 